\title{
The effect of business environment on firm performance Exploratory Study: Case of Tunisian enterprises
}

\section{Rahma LAOUITI', Samiha GHARBI', Naoufel LIOUANE}

${ }^{1}$ University of Sousse, Street Khalifa El Karoui, Sahloul 4 Sousse 4002 - 526 PB Tunisia

Laouiti.rahma@yahoo.com

${ }^{2}$ PhD. in Management, University of Manouba, University campus of Manouba, Manouba 2010

samiha.gharbi@gmail.com

${ }^{3} \mathrm{PhD}$. in Economics, University of Sousse, Street Khalifa El Karoui, Sahloul 4 Sousse 4002 - 526 PB

Tunisia

naoufel liouane@yahoo.fr

\begin{abstract}
The objective of this paper is to identify the different framework characterizing the business environment and assess their impact on companies' performance in order to identify the most dimension environmental affecting companies' performance; new created as well as developed companies. Three mains categories of the business environment are suggested: socio-cultural, institutional and technological environment.
\end{abstract}

To achieve this goal, our research is based on a literature review on the question followed by an empirical study on a sample of 96 companies to make the association between theory and reality.

An empirical study provides that the institutional and the technological factors are the most positively and significantly related to performance. Regarding the socio-cultural environment has a less significance on companies' performance.

Keywords: Business environment, firm performance, Exploratory Study, Tunisian enterprises.

\section{Council for Innovative Research}

Peer Review Research Publishing System

Journal: International Journal of Management \& Information Technology

Vol. 8, No. 3

editor@cirworld.com

www.cirworld.com, member.cirworld.com 


\section{INTRODUCTION}

The main position of the business creation in economy development left to reflect on elements leading to companies' survival and development. According to Mazara and Guy (2012), the survival and success of start-ups concern at the same time researchers, public authorities and entrepreneurs. Thus, it appears necessary to focus on companies' performance which is an essential key to their survival. In fact, "Business Performance improvements arising from increased manufacturing integration continues to be one of the primary competitive issues of the 1990s" (Bititci, 1995).

Muchiri et al. (2011) highlight that in the face of the current global competition and increasing demands from stakeholders, there is a basic business demand to improve manufacturing performance.

The success of a company depends largely on the characteristics of the entrepreneur, his motivations and his skills and experience to manage its human, financial resources as well as its ability to innovate and approve its existence in a turbulent environment. Although, several studies, focusing on entrepreneurship are conducted to show that the entrepreneur for his motivations and his skills is the main actor in the company creation, its development and success (Mazra and Guy, 2012). In the same context, Estay (2004) stressed the impact of the entrepreneur characteristics in the entrepreneurial activity.

However we cannot neglect the effect of the external environment that may affect the success of companies in the social context, governmental incentives and shared culture among consumers well as competitors' also new technologies. According to Estay (2004) "The path taken in the creation of the business depends specially on the personal characteristics of the businessman and those of the environment in which he is working".

In this logic, Appiah-Adu (1999) stressed the impact of environmental changes on organizational performance; indeed "Basically, effects of environmental changes are incorporated in organizational performance studies in an effort to determine the adaptability of a business to transition in its micro or macro environment."

Several studies focus on the new created companies' performance and the effect of business environment in companies creation; in this study we stressed the impact of the Tunisian business environment on companies performance, new created companies as well as developing ones seeing that the effect of performance cannot be limited to the short term. Indeed, performance is evaluated in corresponding to the fixed objectives and the obtained results.

To better carry out the theoretical debate discussed in this paper, it is important to firstly present a brief history of the national Tunisian context, then to mention an overview of the business environment and its dimensions, then to explore the conception and the measurement system of performance and to raise the theoretical relationship between business environment and performance. The remainder of the paper is organized as follows; section 1 is devoted to present main political, social and economic steps of the national Tunisian context; section 2 is devoted to examine the business environment and to define performance. Whilst section 3 outlines our methodology; whilst Section 4 presents the results analysis; section 5 provides result discussion and section 6 as a conclusion.

\section{Brief history of the national Tunisian context after independence: main political, economic and social steps}

At the time of its independence in 1956, Tunisia had few natural resources and its economy was based mainly on subsistence farming and the exploitation of the ores. However, the government engages on a deliberate policy of accelerated development, with the main objective to heave the country on a level comparable with others countries in Europe on the northern shore of the Mediterranean Sea. The past half century has been marked by four major stages of development.

From 1956 to 1969, this is the period of the construction of the nation. Three initiatives are to be noticed for their political, economic and socio-cultural impact: the promulgation of the Law on Personal Status, the creation of the Central Bank of Tunisia and the national currency the Dinar, an economic development policy based on the cooperative system in agriculture and trade, the creation of industrial poles in various regions of the country, and the beginning of tourism development. In all sectors, the State was the promoter, the owner and the manager.

From 1970 to 1986, this period saw the beginning of a certain openness of the economy. However the control of the market by the government and the official field on the major part of the production prevents a true economic take-off. Significant measures were taken, including the establishment of the Agency for the Promotion of industry, later transformed into Agency for the Promotion of industry and Innovation, the promulgation of the law of April 1972 which provided significant benefits to exporting companies, the enactment of a social pact and the implementation of collective agreements to regulate relations between employers and employees, the beginning of openness to exports, combined with protection of the domestic market, contributed to the creation of jobs and a significant improvement of lives. However, the end of the favorable conditions and the inefficiencies of a nationalized economic system led to a financial, economic and social crisis. The years 1982-86 have been the hardest experienced by Tunisia since independence.

From 1987 to 1994, a new policy was adopted, notably marked by a series of macroeconomic reforms, as part of a Structural Adjustment Program developed in accordance with the World Bank and the International Monetary Fund. Significant changes were initiated, as well as reform the tax system and the introduction of value added taxes, enactment of the investment code, financial sector reforms. 
From 1995, on the basis of the opportunities offered by the European Union (EU), Tunisia has decided to pursue its course of economic extraversion, first country which, in 1995, signed an Agreement Euro-Mediterranean Association with the EU, laying on a global partnership political, economic and socio-cultural and providing for a free trade area; In 1995, acceded to the World Trade Organization (WTO); signed a free trade agreement with certain countries of the Mediterranean region.

\section{LITERATURE REVIEW}

\subsection{The Business Environment: theoretical framework}

The business environment was the main purpose of scholars on the part of the World. Indeed, Estay (2004) offers a cross-cultural analysis of the entrepreneurial environment in France and the USA, The author suggests three main categories: economic, socio-cultural, and political environment. Moreover, the business environment was the main objective of the study conducted by the World Bank; this study aims to understand this environment faced by manufacturing industries in Nepal and to determine how it affects the performance of private sector business enterprises.

Regarding the Tunisian contest, GEM study (2009) focus on the business environment and its impact on the entrepreneurial dynamism; it presents the main framework conditions of entrepreneurial activity in Tunisia. It involves governmental policies, financial environment related with entrepreneurship, professional and commercial infrastructure access, education and formation, valuation of innovation, opportunities creation, and socio-cultural norms. Based on this view of literature, three dimensions of the business environment are discussed in this paper: socio-cultural, institutional and technological environment.

\section{The socio-cultural environment}

According to Minniti (2005), company's social environment becomes important, its participation in a broadly defined network helps to define the contour of the set of its entrepreneurial tasks. In effect, the socio-cultural environment refers in this research to the social network, beliefs, attitudes, behaviors and values of a society.

Moreover several studies argue that the social environment refers to the social capital. The concept of social capital is used by Aldrich (1999) to define the sum of individual's personal relations. It allows businessman to have access to skills, funding or contacts which would be difficult without interpersonal relations (Estay, 2004).

'The setting up of a business demands of its creator to have the ability to develop a social capital and a team loyalty toward the project' (Estay, 2004). In addition, the social capital is placed according to Mazra and Guy (2012) at the heart of entrepreneurial dynamics.

Referring to GEM study, socio-cultural norms are moderately favorable business creation and development in Tunisia; based on expert opinion, risk-taking, the ability to take control of its own destiny, creativity and innovation are less defended by Tunisian society. Nevertheless, a tendency of young people to self-employment can be detected, which could be a structural change in the standards, preferences and attitudes vis-à-vis the risk of the Tunisian economic culture.

\section{The institutional environment}

In this paper the institutional environment corresponds to the institutional frameworks, legal context, in general the governmental policies that affect companies. Company, whatever its legal form worked in an institutional framework which may affect its existence and success (Estay, 2004). According to Mazra and Guy (2012) the role of the government consists essentially in providing favorable conditions for business.

According to Harbi and Anderson (2010), institutions are considered as a set of rules, conventions and norms that set standards of behavior for the members of society. In fact, "Institutions should in general be both efficient and adapted to the existing social and economic environment" (Harbi and Anderson, 2010).

In addition, Stenholm et al., (2013) discuss the policy interventions that could shape the quality of entrepreneurial activity; also they focus on how various institutional arrangements influence both the rate and the type of entrepreneurial activity within a country. Appiah-Adu (1999) highlights the positive impact of the government policies especially developing countries on firm performance; it aims to create more attractive business environments, particularly those better financial and transportation infrastructure.

At the micro level the role of the government is too important in improving business performance while political and governmental actions can influence entrepreneurial activity. Firstly, the legal environment encourages or limits personal initiative. Secondly the setting up of assistance or the aid schemes allow for the realization or development of projects. Finally, the State allocates specific help to entrepreneurs in the form of financial incentives, the opening up of public service contracts or assistance to those experiencing difficulties (Estay, 2004).

The greatest importance attributed to business creation and development by the government of Tunisia is best expressed by fiscal and financial incentives articulated by the Code of Investment Incentives. Promotion of private investment in Tunisia dates back to the early 90 s, Therefore, reforms have been initiated, focusing mainly on the creation of a constructive regulation of a favorable economic environment for private initiative. In this context the investment incentive code was established in 1993 in Law 120 dated December, 27th 1993 this code represents the main regulatory support entrepreneurship program in Tunisia. The main objective of the enactment of this code is to 
simplify and harmonize the system of investment incentives by replacing multiple laws by a unique and general code. It aims to promote exports, encourage regional development, promote agricultural development, and attracts foreign investors in specific sectors and in specific areas, with the exception of mining, energy, domestic commerce and the financial sector.

\section{The technological environment}

The economics and business are two areas strongly influenced by innovation in technology, telecommunications and the methods of producing and managing those projects that achieve greater economic value and ensuring jobs and growth.

Lidia Díaz-Díaz et al. (2008) stressed the importance of the Technological Knowledge Assets in the financial performance of the company; in fact, "achieving a differentiate levels of profitability depends on the firm's capacity to acquire, generate and exploit Technological Knowledge Assets." Also, according to Porter (2001), the competitive advantage depends on the firm capability to adopt new technology (Voola et al., 2012).

Due the different on firm capability and the varying responses to new technologies which may have subsequent effects on firm performance and competitive advantage (Voola et al., 2012). Moreover the literature indicates a positive relationship between firm capabilities and the adoption of innovation, including the adoption of new technologies (Voola et al., 2012).

Based on the results of the investigation started with the experts, the GEM study provides Tunisian both consumer and entrepreneur, have a tendency to innovation and using new technology for either the product or process. This study proves that Tunisia occupies a middle position in terms of efficiency of technology transfer of research structures to new and developing. It should be emphasized that the country has a potential and a progression margin important to improve its international position and achieve significant advancements in enhancing innovation.

\subsection{Firm performance}

The heart of the strategic management process is to achieve the performance outcomes that allow firms to be competitive over time (Zehir et al., 2011). Here we try to define the concept of performance, it measurement method and also we try to present a measurement model that shape.

\section{Theoretical conception}

Performance can be defined as the final result of all activities. The emphasis in evaluating performance is on assessing the current behavior of the organization in respect to its efficiency and effectiveness (Ghosh and Mukherje, 2006).

Performance is a notion that permeates contemporary societies, as it is used to assess the quality of individual and collective efforts. In management research, performance is often perceived as encapsulating the unitary purpose of organizations (Michelia and Mari, 2013).

It is obvious that the concept of performance is systematically perceived in a context of piloting and assessment therefore makes sense when considering an instrumental way.

\section{Performance measurement}

Business performance is multidimensional in nature and accounting measures may be misleading because of their inadequate handling of intangibles and improper valuation of sources of competitive advantage. Scholars specify that methods for measuring organizations performance are defined by management to determine whether the planned objectives have been achieved.

Mazra and Guy (2012) referring to Gilles (1994) classifies the indicators of measures of business performance into objective and subjective measures. Also Galvin (2008) distinguishes objectives and subjective measures, while objective performance data would have been preferred, however subjective performance measures have been shown to be a reasonable substitute for objective measures and have a significant correlation with objective measures of performance.

Objective measures are mainly in the field of accounting and finance, which allow easy comparisons between organizations. However, objective measures provide a good comparison between companies, but these types of measures are not adequate due to the specificity of the sector because of the multiplicity of business activities or difficulties in obtaining accounting information. Even though it may seem legitimate to consider the financial data as the ultimate measure of firm performance, yet there are significant limitations on indicators of accounting performance: the late nature of information, the disconnection between short-term reporting practice and long-term strategies, the capital markets informational purpose rather than decision support (Mazra and Guy, 2012). In addition, Appiah-Adu (1999) uses subjective method while it facilitates better comparability across different industries and conditions, with varying standards of acceptable performance. Besides, Galvin (2008) argued with the subjective method where performance is measured in correspondence to competitors in their industry and about the previous three-year period in order to proximate a notion of sustained performance.

From theses different conception it is evident that performance is a subjective and a multidimensional concept, and it is legitimate to present a multidimensional model of measurement system that balances objectives and subjective measurers, it is the balance of scorecard. 


\section{Model of measuring performance: Balanced SCORECARD}

"There have been a huge variety of measurement systems, starting with the best known ones such as the balanced scorecard" (Estampe et al., 2013).

Balanced Scorecard (BSC), developed in the 1990s, proposes four analytical axes: customers, finance, internal processes and innovation-growth. It is specifically geared towards general management and can be applied from the strategic through the organizational level. It aims to establish causalities between the performances of each analytical axis (Estampe et al., 2013).

Referring to Kaplan and Norton (1996), BSC is a multi-dimensional performance measurement system that balances objective and subjective outcome measures, tracks the past and provides measures that drive future performance (Kraus et al., 2010). The authors discuss the way that the BSC can play a role in piloting an organization by allowing its members to appropriate strategic orientations and to develop a common interpretation of these orientations by clarifying strategic objectives and creating consensus and teamwork among all senior executives (Bessire et al., 2005).

So after having introduce the business environment dimensions and clarifies the concept of performance as well as the impact of this environment on firm performance thus treated in the literature, then we try to investigate this relation empirically on the Tunisian context.

\section{METHODOLOGY AND MODEL \\ 3.1. Sample and data collection}

A questionnaire survey method was used to collect data for validating the constructs of our proposed framework; our survey was presented in French and destined for entrepreneurs or managers of private Tunisians companies in the period of Mars and April 2013.

Respondents are asked about their perception on the business environment (socio-cultural, institutional and technological environment) initially, and then they are asked to evaluate their business according to four dimensions of performance measure (financial, customer, internal process and innovation-growth perspectives) referring to the Balanced Scorecard. The questionnaire was mailed with a cover letter explaining the purpose of the survey where they are assured of the anonymity and confidentiality of their information.

We have initially selected a sample consisting of 120 firms. So after the administration of the questionnaire, face to face and using electronic means followed by several reminders in some companies, we ended with 96 questionnaires, representing $80 \%$ of the initial sample. Entrepreneurs/ managers were asked on a five-point Likert-type scale to indicate their perception of the business environment.

\subsection{Variables and model}

\section{Independent variables: business environment}

Several researches are focusing in the fundamental framework conditions characterizing entrepreneurial activity, these conditions, according to GEM study, relate to the following areas: finance, government policies, programs and specific actions, education and training, transfers, research and development, legal and commercial infrastructure, physical infrastructure, opening the domestic market, socio-cultural norms.

In this context Estay (2004) presents the main categories of entrepreneurial environment: economic environment, socio-cultural environment, demographics characteristics of the entrepreneurs (motives of business creation, gender and level of education and income of entrepreneurs) and the political factors including the legal environment, support program and aids given. In our research, three dimensions of the business environment are retained; the sociocultural, institutional and technological environment.

\section{Dependant variables: firm performance}

To measure performance two general approaches are retained: objective and subjective measures. The objective approach uses the absolute values of quantitative performance measures such as profitability, cash flow and market share. The second approach uses subjective measures of performance, where respondents are asked to state their companies' performance on criteria like profitability and market share relative to that of their competitors. In our research, the subjective method was adopted because of the unavailability of objective information. Respondents are asked about their perception on evaluating their business on 4 dimensions of performance; their satisfaction was assessed on a Likert-type scale with 5 point from not at all satisfied to totally satisfy.

Referring to the balanced of scorecard model, four perspectives are retained to measure business performance: financial, customer, internal process and innovation-growth perspectives.

Financial perspective is measured by means of four essential items: turnover, profit, ROE, ROA. Customer perspective is explained by means of four items: reputation or branding, customer satisfaction, product or service quality and market share. Concerning the internal processes perspective, four items are used: recovery policy, innovation and differentiation, flexibility related to the needs of consumers and costs add value. The innovation-growth perspective is explained by three indicators: competence of the employees, employee satisfaction and productivity. 


\section{DATA ANALYSIS}

The data were processed in SPSS. Three types of statistical analysis were mobilized: Initially, we proceed by descriptive analysis such as principal component factor analysis for the purification of scales measuring business environment dimensions and performance; in the second step, we have applied the correlation analysis between dependent and independent variables; a multiple linear regression to test our research hypothesis taking into account the business environment dimensions and performance.

\section{1. $\quad$ Purification of measurement scales}

\section{Purification of measurement scales business environment dimensions}

The socio-cultural dimension is measured in this paper by a set of four items; the reliability analysis gives a value of Cronbach's alpha equal to 0.717 ; this coefficient is very satisfactory as far above the theoretical recommended minimum.

After performing a factor analysis, the result shows a value of $\mathrm{KMO}=0.731$, this result proves a good fit between items, this is also confirmed by the Bartlett test with a value of 80.585 with a significance level of 0.000 . The factor analysis result shows that the variable 'socio-cultural context' is one-dimensional and all items are well correlated to that axis which explains $57.108 \%$ of the total variance in this dimension.

Table 1: factor analysis on socio-cultural environment

\begin{tabular}{|c|c|c|c|c|c|}
\hline Items & $\begin{array}{l}\text { commonality } \\
\text { (QR) }\end{array}$ & F1 & Value & Variance (\%) & $\begin{array}{l}\text { Cumulated } \\
\text { variance (\%) }\end{array}$ \\
\hline Item1 & 0,428 & 0,654 & 2,284 & 57,108 & 57,108 \\
\hline Item2 & 0,734 & 0,857 & 0,729 & & \\
\hline Item3 & 0,511 & 0,715 & 0,610 & & \\
\hline Item4 & 0,611 & 0,782 & 0,376 & & \\
\hline
\end{tabular}

The institutional environment is expressed by seven items; the reliability test gives a Cronbach's alpha equal to 0.687 ; this result is satisfactory and asserts the reliability of items. The factor analysis gives a value of $\mathrm{KMO}=0.666$; it proves a good fit between our results and processing techniques. This satisfactory is also confirmed by the Bartlett test with a value of 127.304 , significant at a level of 0.000 . It appears from this result that this variable have three relevant axes; these axes explained $71.577 \%$ of the total variance of our sample.

Table 2: factor analysis on institutional environment (after rotation)

\begin{tabular}{|l|l|l|l|l|l|l|}
\hline Items & $\begin{array}{l}\text { communalities } \\
\text { (QR) }\end{array}$ & F1 & F2 & F3 & $\begin{array}{l}\text { Variance } \\
\text { (\%) }\end{array}$ & $\begin{array}{l}\text { Cumulated variance } \\
\text { (\%) }\end{array}$ \\
\hline Item1 & 0,656 & 0,759 & & & 31,578 & 31,578 \\
Item2 & 0,770 & 0.872 & & & 23,243 & 54,821 \\
Item3 & 0,753 & 0.866 & & & 16,756 & 71,577 \\
Item4 & 0,606 & 0.304 & & & & \\
Item5 & 0,718 & & 0.842 & & & \\
Item6 & 0,751 & & 0.856 & \multirow{2}{*}{0.834} & & \\
Item7 & 0,755 & & & & & \\
\hline
\end{tabular}

For the technological environment, four items are used; the reliability test gives a value of Cronbach' alpha equal to 0.724 , this value is satisfactory. The factor analysis shows a value of KMO of 0.694 , this value proves a good fit between results and the adopted processing techniques. This satisfactory is also confirmed by the Bartlett test with a value of 142.271 with a significance level of 0.000 . The result shows that the variable 'technological environment' is one-dimensional and all items are well correlated to that axis which explains $60.546 \%$ of the total variance in this dimension.

Table 3: factor analysis on technological environment

\begin{tabular}{|l|l|l|l|l|l|}
\hline Items & $\begin{array}{l}\text { Commonalities } \\
\text { (QR) }\end{array}$ & F1 & Value & Variance (\%) & $\begin{array}{l}\text { Cumulated } \\
\text { variance } \\
\text { (\%) }\end{array}$ \\
\hline Item1 & 0,428 & 0.261 & 2,422 & 60,546 & 60,546 \\
Item2 & 0,734 & 0.863 & 0,999 & & \\
Item3 & 0,511 & 0.897 & 0,360 & & \\
Item4 & 0,611 & 0.897 & 0,219 & & \\
\hline
\end{tabular}




\section{Purification of measurement scales firm performance}

The firm performance is measured using four dimensions: financial, customer, the internal process and innovationgrowth perspective.

The Financial perspective is measured in this paper by four items: turnover, profit, return on equity ROE, return on assets. The reliability analysis gave us Cronbach's alpha equal to 0.933 ; this coefficient is very satisfactory. The result gives an indicator of $\mathrm{KMO}=0.828$, the test of Bartlett is also significant by a value of 316.627 with a level of significance of 0.000 . The factor analysis result shows that the variable 'financial performance' is one-dimensional and the four items are represented by one axis which explains $84,111 \%$ of the total variance.

Table 4: factor analysis on financial perspective

\begin{tabular}{|l|l|l|l|l|l|}
\hline Items & Commonalities (QR) & Factor & Value & $\begin{array}{l}\text { Variance } \\
(\%)\end{array}$ & $\begin{array}{l}\text { Cumulated } \\
\text { variance } \\
(\%)\end{array}$ \\
\hline Item1 & 0,849 & 1 & 3,364 & 84,111 & 84,111 \\
Item2 & 0,912 & &, 312 & & \\
Item3 & 0,839 & &, 228 & & \\
Item4 & 0,765 & &, 096 & & \\
\hline
\end{tabular}

Customer perspective is measured by fours items: reputation or branding, customer satisfaction, product or service quality and market share. The reliability test gives a value of Cronbach' alpha equal to 0.855 ; the results indicates a value of $\mathrm{KMO}$ equal to 0.819 ; this result is significant and proves a good fit between our observations and the adopted processing techniques. This satisfaction is also confirmed by Bartlett test with a value of 143.657, significant at a level of 0.000 . This result also shows that the variable 'customer perspective' is one-dimensional and items are well correlated to that axis which explains $69,768 \%$ of the total variance in our sample.

Table 5: factor analysis on customer perspective

\begin{tabular}{|l|l|l|l|l|l|}
\hline Items & Commonalities (QR) & Factor & Value & $\begin{array}{l}\text { Variance } \\
(\%)\end{array}$ & $\begin{array}{l}\text { Cumulated } \\
\text { variance } \\
(\%)\end{array}$ \\
\hline Item1 & 0,703 & 1 & 2,791 & 69,768 & 69,768 \\
Item2 & 0,729 & &, 491 & & \\
Item3 & 0,725 & &, 373 & & \\
Item4 & 0,634 & &, 346 & & \\
\hline
\end{tabular}

The internal process perspective is explained by four items: recovery policy, innovation and differentiation, flexibility related to the needs of consumers and costs add value. The reliability analysis of these items gives a value of Cronbach' alpha equal to 0.765 , The result shows $\mathrm{KMO}$ indicator with a value of 0.732 , and the Bartlett test equal to 103.467 with a significance of 0.000 . The result indicates that the variable 'internal processes' is one dimensional and the fours items are well correlated to this axis which explain $59,738 \%$ of the total variance.

Table 6: factor analysis on internal process perspective

\begin{tabular}{|l|l|l|l|l|l|}
\hline Items & commonality (QR) & Factor & Value & $\begin{array}{l}\text { Variance } \\
(\%)\end{array}$ & $\begin{array}{l}\text { Cumulated } \\
\text { variance } \\
(\%)\end{array}$ \\
\hline Item1 & & & & & 59,738 \\
Item2 & 0,305 & 1 & 2,390 & 59,738 & \\
Item3 & 0,773 & & 0,819 & & \\
Item4 & 0,678 & & 0,472 & & \\
\hline
\end{tabular}

The innovation-growth perspective is explained by three items: competence of the employees, employee satisfaction and productivity. Reliability analysis gives a value of Cronbach' alpha equal to 0.901 , the factor analysis indicates a value of $\mathrm{KMO}$ indicator equal to 0.740 and Bartlett test with a value of 160.818 significant at 0.000 . This result also shows that customer perspective is one-dimensional and items are well correlated to that axis which explains $83,601 \%$ of the total variance in our sample. This axis can be called 'productivity'.

Table 7: factor analysis on innovation and growth perspective

\begin{tabular}{|l|l|l|l|l|l|}
\hline Items & commonality (QR) & Factor & Value & $\begin{array}{l}\text { Variance } \\
(\%)\end{array}$ & $\begin{array}{l}\text { Cumulated } \\
\text { variance } \\
(\%)\end{array}$ \\
\hline Item1 & & & & & 83,601 \\
Item2 & 0,874 & 1 & 2,508 & 83,601 & \\
Item3 & 0,824 & & 0,299 & & \\
\hline
\end{tabular}


The four dimensions of business performance can be summarized in one dimension 'Global PERFRORMANCE', with the purpose of ending up with one linear regression model. Reliability test gives a value of Cronbach Alpha equal to 0.840 which is satisfactory indicator. The application of the factor analysis gives a KMO indicator equal to 0.778 ; the Bartlett test is significant at 0.000 with a value of 135,127 . The result shows that global performance is one dimensional and the four items are correlated to this axis which explains $67,918 \%$ of the total variance.

Table 8: factor analysis on global Performance

\begin{tabular}{|l|l|l|l|l|l|}
\hline Items & commonality (QR) & Factor & Value & $\begin{array}{l}\text { Variance } \\
(\%)\end{array}$ & $\begin{array}{l}\text { Cumulated } \\
\text { variance } \\
(\%)\end{array}$ \\
\hline Item1 & 0,638 & 1 & 2,717 & 67,918 & 67,918 \\
Item2 & 0,696 & & 0,578 & & \\
Item3 & 0,560 & & 0,462 & & \\
Item4 & 0,824 & 0,243 & & \\
\hline
\end{tabular}

\subsection{Correlation analysis: Pearson's correlation}

The nature of the business environment and performance relationships was examined on a bivariate basis. Pearson correlation coefficient was calculated for each hypothesized relationships and correlation analysis illustrates three significant associations;

For the socio-cultural environment, this analysis support the hypothesized association with the innovation and growth perspective and the global performance

Concerning the legal context, our result shows a positive and significant correlation with the customer perspective, the correlation coefficient is 0,334 significant at $5 \%(0.003)$. In term of the internal process, the coefficient of correlation is equal to 0,263 and is significant at $5 \%(0.020)$. Moreover, the legal context is significantly related to the firm performance in global; the coefficient of Pearson is equal to 0.292 and is significant at $5 \%(0.011)$.

The technological environment is significantly related to the customer perspective with a Pearson coefficient equal to 0.277 significant at $5 \%(0.010)$, concerning the internal process perspective, the correlation coefficient is 0.339 and it is significant at $5 \%(0.001)$.

As regards the innovation and growth perspective, a significant correlation coefficient is equal to 0.384 .In terms of global performance technological factors are significantly related to business performance with a Pearson coefficient equal to 0.314 significant at $5 \%(0.004)$.

\subsection{Linear regression}

This section identifies and analyzes factors that have influenced the firm performance. We proceeded with linear regression analysis to identify the determinants of firm performance,

In this analysis three dependent variables are included, namely the socio-cultural, institutional and technological environment; Concerning the institutional environment we have retained the first axis as it explains $31,578 \%$ of the total variance, while the second and the third axis explains respectively 23,243 and $16,756 \%$. The question is which of these types of environment is the most related to the firm performance. The linear regression model linking these dimensions is presented as follow:

$P E R F=a+\beta 1(S O C L)+\beta 2(L E G L)+\beta 3(T E C H)+\varepsilon$

Where $\mathrm{PERF}=$ business performance; $\mathrm{SOCL}=$ socio-cultural context; $\mathrm{LEGL}=$ legal context; $\mathrm{TECH}=$ technologies factors and $\varepsilon$ presents the error.

As shown one equation is matched and the results are shown in Table 9. We had to try several equations because of the multiplicity of our dependent variables.

The result shows a correlation coefficient $R$ of 0.431 and a determining coefficient of $R^{2}$ of 0.186 . The multiple correlation coefficient $\mathrm{R}$ is greater than 0 , which means that there is a direct relationship between variables. The coefficient of determination R Square (R2) is 0,186 and means that $18.6 \%$ of the variation in firm performance can be explained using analyzed variables. The Fisher test gives $F$ value equal to 5.324 with a significance of 0.002 ; this test shows the role of independent variables in explaining the evolution of the dependent variable. This result shows that the regression model is valid and can be used to analyze the dependence between variables.

Table 9 also shows a DW value equal to 1.988 (less than 2), that's mean that the regression models assume that the error deviations are uncorrelated. Regarding the Student's test, the results highlight that two of the three dimensions of the business environment are significantly related to firm performance. These are the technological factors (significant at 0.016) and the legal factors (significant at 0.094). The dimension socio-cultural context is not significantly related to firm performance. 
Table 9: Summary results of the linear regression

\begin{tabular}{|l|l|l|l|l|}
\hline $\begin{array}{l}\text { Dependant variable: } \\
\text { business performance }\end{array}$ & Constant & $\begin{array}{l}\text { Socio-cultural } \\
\text { context }\end{array}$ & Legal factors & $\begin{array}{l}\text { Technological } \\
\text { factors }\end{array}$ \\
\hline $\begin{array}{l}\text { Coefficient } \\
\text { t-student }\end{array}$ & $\begin{array}{l}0,029 \\
(0,257)\end{array}$ & $\begin{array}{l}0,115 \\
(0,960)\end{array}$ & $\begin{array}{l}0,210 \\
(\mathbf{1}, 698)^{\star}\end{array}$ & $\begin{array}{l}0,280 \\
(\mathbf{2 , 4 6 6})^{\star \star}\end{array}$ \\
\hline $\begin{array}{l}\text { F Value } \\
\text { R-square } \\
\text { DW }\end{array}$ & 5,324 & & \\
\hline
\end{tabular}

** Significant at level 5\%, * Significant at level 10\%

\section{RESULT DISCUSSION}

Our survey allows arriving at some inputs or confirmations concerning the effect of the business environment in firm performance in the Tunisia context. As expected, performance is affected positively by the business environment framework. The correlation analysis between dependant and the independent variables indicates that the sociocultural environment is related to the innovation-growth perspective and the performance in global.

Moreover, the legal context is related, based on the correlation matrix, to the customer perspective and the internal processes perspective and accordingly the global performance.

As regards the technological environment, the correlation analysis revealed that it relates to the customer perspective and the internal processes performances and to innovation-growth perspective, hence it also relates to the performance in global.

In addition, this study develops a conceptual model to investigate the relationship linking the business environment dimensions and performance; the result shows that the technological and the legal context are determinant of performance. The significant link of the performance with the technological environment can be explained by the fact that the adoption of new technologies allows companies to be more competitive by introducing innovations in the process or in the product.

Our result indicates that the legal context is significantly related to performance, this relation can be demonstrated by the important role that play the government in improving business environment throw investment incentive laws. Also, we find up that the socio-cultural context is not significantly related to business performance; against our hypothesis concerning the socio-cultural context in Tunisia.

\section{CONCLUSIONS}

The business environment is the prerequisite for a successful business operation. To test the assertion empirically, this study looks into the nature of the correlation between business environment framework conditions and company performance.

To achieve our objective, we have processed with the quantitative approach using a questionnaire survey method; we have used the subjective method in order to evaluate entrepreneur's perception about the business environment and their valuation of their business.

The business environment was hypothesized as three-dimensional: socio-cultural, institutional and technological environment. Our dependent variable is measured, using four dimensions referring to the balanced of Scorecard of Kaplan and Norton (1996), which represent one of the most known model of measure of business performance using financial and no-financial indicators.

After applying the factor analysis at the aim of the reduction of our variables for each dimension in one axis, we have processed with the correlation analysis, the result of this analysis indicates a significant correlation coefficient among the business environment in its three dimensions (socio-cultural, institutional and technological) in one hand and firm performance in the other hand.

The purpose of the linear regression is to specify the dimension of the business environment that affects the most firm performance; our result shows that technological environment is the most related to business performance, followed by institutional environment. Regarding the socio-cultural environment, our result shows that these factors are less important in improving firm performance.

\section{REFERENCES}

[1] Appiah-Adu, K. (1999), "The impact of economic reform on business performance: a study of foreign and domestic firms in Ghana", International Business Review, 8, p.463-486. 
[2] Bessire D., Baker C.R. (2005), "The French Tableau de bord and the American Balanced Scorecard: a critical analysis", Critical Perspectives on Accounting 16, p.645-664.

[3] Bititci, U.S. (1995), "Modelling of performance measurement manufacturing enterprises", International Journal Production Economics, 42, p.137-147.

[4] Code des incitations aux investissements (2010), Imprimante officielle de la République Tunisienne, p. 616.

[5] Díaz-Díaz, N.L., Aguiar-Díaz, I., De Saá-Pérezc, P. (2008), "The effect of technological knowledge assets on performance: The innovative choice in Spanish firms", Research Policy 37, p.1515-1529.

[6] Doing Business, (2013), des réglementations intelligentes pour les petites et moyennes entreprises, $10^{e}$ édition, Une publication conjointe de la Banque mondiale et de la Société financière internationale, p. 27.

[7] El Harbi, S., Anderson, A.R. (2010), "Institutions and the shaping of different forms of entrepreneurship", The Journal of Socio-Economics 39, p. 436-444.

[8] Estampe D., Lamouri S., Jean-LucParis J., SakinaBrahim-Djelloul S.B. (2013), "A framework for analysing supply chain performance evaluation models", International Journal Production Economics 142, p.247-258.

[9] Estay, C. (2004), "Setting up Businesses in France and the USA: A Cross Cultural Analysis", European Management Journal, 22, 4, p. 452-463.

[10] Evaluation d'opérations d'appui budgétaire - Etudes relatives à la coopération entre la CE et la Tunisie entre 1996 et 2008, Volume 1 - Rapport Principal, (Mars 2011) Evaluation pour la Commission Européenne.

[11] Ghosh, S., Mukherjee, S. (2006), "Measurement of firm performance through balanced scorecard: an overview", Vidyasagar University Journal of Commerce, 11, p.60-70.

[12] Hoque, Z. (2004), "A contingency model of the association between strategy, environmental uncertainty and performance measurement: impact on organizational performance", International Business Review, 13, p. 485-502.

[13] Kraus, K., Lind, J. (2010), "The impact of the firm balanced scorecard on firm control-a research note", Management Accounting Research 21, p. 265-277.

[14] Li, Y.H., Huang, J.W., Tsai, M.T. (2009), "Entrepreneurial orientation and firm performance: The role of knowledge creation process", Industrial Marketing Management 38, p. 440-449.

[15] Mansouri, F., Belkacem, L. (2009), Tunisia Executive Report, GEM Global Entrepreneurship Monitor, p. 68.

[16] Mazra, M., Guy, O.R. (2012), "Empirical and Explanatory Approach of Support Effect on Newly Created Firms' Performance”, Journal of Management and Sustainability, 2, P. 293-304.

[17] Micheli, P., Mari, L. (2013), "The theory and practice of performance measurement". Management Accounting Research, p. 1-10.

[18] Muchiri, P., Pintelon, L., Gelders, L., Martin, H. (2011), "Development of maintenance function performance measurement Framework and indicators", International Journal Production Economics, 131, p.295-302.

[19] Stenholm, P., Acs, Z.J., Wuebker, R. (2013), "Exploring country-level institutional arrangements on the rate and type of entrepreneurial activity", Journal of Business Venturing, 28, p. 176-193.

[20] Tchuigoua H.T. (2010), "Is there a difference in performance by the legal status of microfinance institutions?", The Quarterly Review of Economics and Finance, 50, p.436-442.

[21] Voola, R., Casimir, G., Carlson, J., Agnihotri, M.A. (2012), "Adoption on performance: a moderated mediation analysis", Australasian Marketing Journal, 20, p. 136-146.

[22] Zehir C., Altindag E., A.ZaferAcar A. (2011), "The Effects of Relationship Orientation through Innovation Orientation on Firm Performance: An Empirical Study on Turkish Family-Owned Firms", Procedia Social and Behavioral Sciences, 24, p.896-908. 